\title{
Analisis Model Altman Z-Score Dalam Memprediksi Kebangkrutan Pada Perusahaan Perbankan Swasta Nasional Devisa Yang Go Public Di Bursa Efek Indonesia (Periode 2015-2017
}

\author{
Yuhronur Efendi, Mahrus, Dedik Wijayanto \\ Program Studi Magister Manajemen, Universitas Islam Lamonagan \\ Email authors: yuhronurefendi@unisla.ac.id, mahrus_12@gmail.com \\ dedikwijayanto@gmail.com
}

\begin{abstract}
ABSTRAK
Perbankan di Indonesia mempunyaiperanan yang sangatpenting, namun tidak menutup kemungkinn perbankan swasta di Indonesia mengalamikegagalan keuangan yang disebabkan oleh biaya modal perusahaan yang lebih besar dari pada tingkat laba biayahistorisinvestasi.Oleh karena nya penelitian akan estimasi kebangkrutan dibutuhkan untuk meminimalisir kerugian di masa datang. Untuk memprediksikan kapan suatu perusahaan akan bangkrut dapat menggunakan lima rasio keuangan. Penelitian ini bertujuan untuk mengetahui kondisi rasio-rasio keuangan dan mengetahui apakah analisis model Altman Z-Score dapat menunjukan kebangkrutan suatu bank swasta di Indonesia. Teknik analisis data yang digunakan adalah metode Altman Z-score. Hasil dari penelitian ini menunjukan bahwa perusahaan perbankan periode 2015-2017 memiliki rata-rata perusahaan perbankan swasta yang berada pada tingkat grey area. Karena nilai Z" (Z-score) suatu perusahaan perbankan swasta mengalami fluktuatif (berubah-ubah secara tidak signifikan). Dengan adanya penelitian ini, penulis mengharapkan apabila faktor-faktor tersebut dapat diperoleh dan dapat diukur dengan tepat, maka akan diperoleh tingkat prediksi kebangkrutan suatu perusahaan yang lebih akurat.
\end{abstract}

Kata Kunci : Altman Z-score, Laporan keuangan, Bank Swasta Nasional Pelanggan

\section{PENDAHULUAN}

Perbankan merupakan urat nadi perekonomian di seluruh bangsa. Setelah terjadi krisis, pada bulan Juli 1998 nilai mata uang rupiah mengalami penurunan, indeks saham terpangkas menjadi $35 \%$, kapitalisasi pasar berkurang sebesar $88 \%$, tingkat pengangguran meningkat $16,8 \%$, suku bunga meningkat 65\%, dan nilai impor menurun hingga 33,4\% (Kompas, 23 Juli 1998). Kondisi ini membuat para investor dan kreditur khawatir jika perusahaannya mengalami kesulitan keuangan yang bisa mengarah kekebangkrutan.Menurut Sunarto (2006)Kebangkrutan atau kepailitan adalah kegagalan bisnis yang terjadi apabila kewajiban / hutang-hutang perusahaan lebih besar daripada nilai pasar yang wajar dariaktiva-aktivanya. Sehingga kebangkrutan merupakan ketidakmampuan suatu perusahaan dalam melanjutkan kegiatan operasinya dikarenakan kondisi keuangan yang dimiliki mengalami penurunan dan memiliki kewajiban atau hutang yang jumlahnya lebih besar dari nilai aktivanya.

Tugas penting manajeman atau investor setelah akhir tahun adalah menganalisa laporan keuangan perusahaan. Laporan keuangan diperlukan oleh pihak-pihak yang berkepentingan, dimana pihak-pihak tersebut memiliki kepentingan yang berbeda-beda. Oleh karena itu laporan keuangan harus disusun sedemikian rupa sehingga memenuhi kebutuhan semua pihak Kasmir (2003). Menurut Munawir (2010) ada beberapa teknik analisis yang biasa digunakan oleh para analis dalam menganalisis laporan keuangan. Analisa laporan keuangan terdiri dari dua yaitu analisa dan laporan keuangan, analisa adalah memecahkan atau menguraikan suatu unit menjadi berbagai unit terkecil. Sedangkan laporan keuangan secara singkat adalah neraca, laba/rugi, dan arus kas (dana).Fraser dan Ormiston (2004)menyatakan bahwa rasio keuangan adalah perhitungan yang dilakukan untuk menstandarisasikan, menganalisis, dan membandingkan data keuangan yang dinyatakan hubungan."

Dengan melakukan analisis secara mendalam terhadap keuangan, tanda-tanda melemahnya kondisi fundamental perusahaan dapat terlihat. Menurut Lesmana(2003)resikok berhubungan 
dengan ketidak pastian mengenai kemampuan atas suatu perusahaan untuk melanjutkan kegiatan operasinya jika kondisi keuangan yang dimiliki mengalami penurunan.Analisis kesulitan keuangan akan sangat membantu pembuatan keputusan untuk menentukan sikap terhadap perusahaan yang mengalami kesulitan keuangan.Edward I. Altman (1968) adalah penemu perihal prediksi akan timbulnya keadaan bangkrut. Ia merupakan orang pertama yang secara sukses menerapkan Mulitiple Discriminant Analysis (MDA) untuk mengembangkan model prediksinya dengan tingkat keakuratan yang tinggi. Penggunaan sampelnya dilakukan pada 66 perusahaan, 33 gagal dan 33 sukses. Tingkat keakuratan yang dicapai oleh model Altman's yaitu sebesar 95\%. Oleh karena itu, perlu dicari model tentang petunjuk adanya perusahaan yang mengalami kesulitan keuangan dan mungkin mengalami kebangkrutan. Berdasarkan pemaparan diatas, penulis tertarik untuk melakukan penelitian pada Bank Swasta Nasional Devisa yang listing di BEI mengenai keandalan analisis rasio keuangan dalam memprediksi kebangkrutan disuatu perusahaan. Metode analisis rasio keuangan sangat beraneka ragam. Salah satunya yaitu metode Altman Z-Score. Metode ini ditemukan oleh orang Amerika bernama Altman. Altman menggunakan Multiple Discriminant Analysis (MDA) yang merupakan salah satu teknik statistik yang menghasilkan suatu indeks dimana nantinya memungkinkan pengklasifikasian dari suatu pengamatan menjadi satu dari beberapa pengelompokan yang bersifat a priori.Berdasarkan uraian pada latar belakang penelitian, dasar penelitian ini adalah untuk mengkaji kemampuan rasio keuangan dengan identifikasi masalahsebagaiberikut (1) Bagaimanakondisirasiorasiokeuangan model Altman Z-Score padaperusahaan perbankan swasta yang go public di BEI (2) Bagaimana analisis model Altman Z-Score dapat menunjukan kebangkrutan pada perusahaan perbankan swasta yang go public di BEI.

\section{METODE PENELITIAN}

Dalam penelitian ini menggunakan jenis penelitian deskriptif kuantitatif. Penelitian ini mengunakan data laporan keuangan 5 Bank Swasta Nasional yang go public di Bursa Efek Indonesiamulai tahun 2015 - 2017 untuk dianalisis dengan menggunakan analisis altman zscore. Variabel- variabel yang akan di akomodir dalam penelitian ini adalah Model Altman ZScore dinyatakan juga dalam variabel dependen yaitu Y. Dalam analisis kebangkrutan peneliti menggunakan model Altman Z-Score yang mencakup lima rasio keuangan yaitu :

a) WCTA $=\frac{\text { workingcapital }}{\text { totalasset }}$

b) RETTA $=\frac{\text { RetainedEarnings }}{\text { totalasset }}$

c) $\mathrm{BVTL}=\frac{\text { MarketValueofEquity }}{\text { BookValueofTotalLiabilities }}$

d) SATA $=\frac{\text { SALES }}{\text { totalasset }}$

e) $\mathrm{EBTTA}=\frac{\text { EBTTA }}{\text { totalasset }}$

Dari penelitian yang dilakukan maka peneliti menetapkan populasi penelitian ini adalah data laporan keuangan 5 Bank swasta nasional yang go public di BEI. Sedangkan sampelnya adalah Laporan keuangan mulai tahun 2015-2017. Analisis data yang akan digunakan pada penelitin ini adalah menggunakan ratio WCTA, RETTA, BVTL, SATA, EBTTA.

\section{TEMUAN DAN PEMBAHASAN}

Dalam menilai kinerja kondisi financial distress, perusahaan perlu memasukan rasio-rasio keuangan kedalam model Altman yang dapat menentukan besarnya kemungkinan kebangrutan. Analisis kondisi financial distress dilakukan untuk memperolehperingatan awal kebangkrutan. Semakin awal tanda-tanda kebangkrutan tersebut, semakin baik bagi pihak manajemen karena pihak manajemen bisa melakukan perbaikan-perbaikan. 
Bedasarkan data laporan keuangan lima perusahaan perbankan yang di peroleh dari website Bursa Efek Indonesia (www.idx.co.id), maka dilakukan analisis laporan keuangan menggunakan analisis diskriminan Altman $z$-score dengan menggunakan persamaan model Altman yaitu :

\section{$Z "=6,56 X_{1}+3,26 X_{2}+6,72 X_{3}+1,05 X_{4}$}

Klarifikasi Bank yang sehat dan tidak sehat didasarkan pada nilai z-score model Altman Modifikasi yaitu : jika nilai Z" $<1,1$ maka bank termasuk dalam Bank yang tidak sehat, jika nilai Z" $<2,6$ maka termasuk grey area ( tidak dapat ditentukan apakah bank sehat ataupun tidak sehat), dan jika nilai Z" > 2,6 maka terasuk bank dalam keadaan yang sehat.

Dibawah ini disajikan data klasifikasi perbankan swasta yang terdaftar di Bursa Eek Indonesia. Dari data ini dapat ditemukan beberapa klasisfikasi kesehatan bank dengan beberapa macam klasifikasi yakni grey area, sehat, dan tidak sehat.

Tabel 1.Klasifikasiperbankanswasta yang terdaftar di Bursa EfekIndonesia

\begin{tabular}{|c|c|c|c|c|}
\hline No & Perusahaan & Tahun & Z'-Scoore & Klasifikasi \\
\hline \multirow{4}{*}{1} & PT Bank Central Asia Tbk & 2015 & 1,548 & Grey area \\
\cline { 3 - 5 } & & 2016 & 1,643 & Grey area \\
\cline { 3 - 5 } & & 2017 & 1,699 & Grey area \\
\hline \multirow{2}{*}{2} & \multirow{2}{*}{ PT Bank Maspion Tbk } & 2015 & 0,911 & TidakSehat \\
\cline { 3 - 5 } & & 2016 & 1,081 & Grey area \\
\cline { 3 - 5 } & & 2017 & 1,245 & Grey area \\
\hline \multirow{2}{*}{3} & PT Bank Capital Indonesia Tbk & 2015 & 2,314 & Grey area \\
\cline { 3 - 5 } & & 2016 & 2,732 & Sehat \\
\cline { 3 - 5 } & & 2017 & 2,703 & Sehat \\
\hline \multirow{2}{*}{4} & PT Bank DanamonTbk & 2015 & 14,704 & Sehat \\
\cline { 3 - 5 } & & 2016 & 12,282 & Sehat \\
\cline { 3 - 5 } & & 2017 & 15,076 & Sehat \\
\hline \multirow{2}{*}{5} & PT Bank CIMB NIAGA Tbk & 2015 & 1,549 & Grey area \\
\cline { 3 - 5 } & & 2016 & 2,225 & Grey area \\
\cline { 3 - 5 } & & 2017 & 2,347 & Grey area \\
\hline
\end{tabular}

Sumber : data diolah, 2019

PT Bank Central Asia Tbk termasuk dalam kategori perbankan yang grey area karena nilai Z" < 2,6. Nilai Z" pada tahun 2015-2017 yaitu 1,548,1,643, dan 1,699.Namun meski demikian nilai Z" pada Bank Central Asia terus mengalami kenaikan meski tidak signifikan, hal ini terjadi karena kondisi perbankan tersebut cenderung stabil meningkat.PT Bank Maspion Tbk adalah satu-satunya bank yang masuk dalam kategori tidak sehat yakni padatahun 2015 dimana nilai Z" $<1,1$. Pada tahun 2015 nilai Z" adalah 0,937.Tapi meskipun pada 2015 Bank Maspion termasuk dalam kategori tidak sehat, namun di tahun 2016 dan 2017 mereka mengalami kenaikan meski tidak terlalu signifikan, kenaikan ini di karenakankeuangan Bank Maspion cukup stabil pada tahun berikutnya.

PT Bank Capital Indonesia Tbktermasukdalamkategoriperusahaan yang Sehat karena nilai Z" $<2,6$ pada tahun 2015 yaitu dengan 2,314. Pada tahun 2016 nilai Z" mengalamikenaikandengan 2,732 danmembuat PT Bank Capital Indonesia berada dalam posisi 
Sehat, dan pada 2017 Bank Capital Indonesia kembali mengalami penurunan. Meskipun nilai Z” pada Bank Capital Indonesia Tbk terjadi penurunan dan kenaikan, namun nilainya tidak terlalu signifikan, hal ini terjadi karena keuangan perusahaan tersebut cenderung stabil. PT Bank Danamon Tbk adalah satu-satunya bank yang sehat karena nilai Z">2,6. Nilai Z" mulai tahun 2015 sampai 2017 mengalami naik-turun, pada tahun 2015 nilai Z" 14,704 sedangkan pada tahun 2016 turun menjadi 12,282 dan pada tahun 2017 naiklagimenjadi 15,076. Padatahun2016 nilai $Z$ " mengalamipenurunankarenanilai $X_{1}$ mengalami penurunan, hal ini bias mempengaruh ini lai Z" menjadi turun juga. Sedangkan pada tahun 2017 nilai $\mathrm{X}_{1}, \mathrm{X}_{2}, \mathrm{X}_{3}$, dan $\mathrm{X}_{4}$ mengalami kenaikan, oleh karena itu pada tahun 2017 nilai Z" menjadi 15,076.

PT Bank CIMB NIAGA Tbk termasuk dalam kategori bank yang gray area (tidak dapat ditentukan apakah bank sehat ataupun tidak sehat), karena nilai Z" $>1,1$. nilai Z" pada tahun 2015-2017 yaitu 1,594, 2,225, 2,347. Namun meski demikian tetapi bank Cimb Niaga setiap tahunya selalu bisa meningkatkan keuangan mereka dan membuat nilai Z" menjadi meningkat tiap tahunya. Penigkatan ini pun tidak terlepas karena aset lancar mereka lebih tinngi nilainya dari pada nilai hutang mereka.

\section{KESIMPULAN DAN SARAN}

Berdasarkan uraian teori, hasil pengolahan dan analisis data yang telah dikemukakan sebelumnya, maka penulis menarik simpulan bahwa Berdasarkan hasilZ-score menunjukkan bahwa empat perusahaan diprediksi bangkrut yaitu: PT. Adaro Energy, Tbk, PT. PerdanaKarya Perkasa, Tbk, PT. Atlas Resource, Tbk, dan PT. ByanResource, Tbk, dan empat perusahaan lain diprediksi dalam keadaan non bangkrut yaitu: PT. Resource Alma Indonesia, Tbk, PT. Indo Tambangraya Megah, Tbk, PT. Bukit Asam, Tbk, dan PT. HarumEnergy, Tbk. Variabelvariabel Altman Z-score dapat digunakan untuk memprediksi tingkat kebangkrutan pada perusahaan tambang namun demikian hal ini hanya sebatas prediksi dan tidak menjamin bahwa perusahaan akan benar-benar bangkrut atau pun tidak. Diharapkan bagi penelitian selanjutnya untuk periodisasi data yang terbatas hanya tiga tahun untuk dapat memprediksi kebangkrutan suatu perusahaan atau organissasi. Kemampuan prediksi akan lebih baik apabila digunakan data time series yang cukup panjang dan memadai. Hendaknya juga menambahkan objek penelitianya pada bank BUMN seperti BNI dan BRI, sehingga akan diketahui kondisi kesehatan yang sesungguhnya dari bank BUMN.

\section{DAFTAR PUSTAKA}

Altman, Edward I. (1968): Financial Ratios, Discriminant Analysis and thePrediction of Corporate Bankruptcy. In: The Journal of Finance, 22(4),589-609

Christina, Amelia, Yana Ulfah, \& Zaki Fakhroni. (2018). Corporate Social Responsibility, Leverage Dan Tax Avoidance : Efek Moderasi Komisaris Independen Corporate Social Responsibility, Leverage and Tax Avoidance : The Effect of Moderation of Independent Commissioners. Seminar Nasional Fakultas Ekonomi dan Bisnis Universitas Mulawarman

Dewi, Kristiana Ni Nyoman, \& I Ketut Jati. (2014). Pengaruh Karakter Eksekutif Karakteristik Perusahaan, Dan Dimensi Tata Kelola Yang Baik Pada Tax Avoidance. E-Jurnal Akuntansi Udayana, 6 (2) : 249-60

Fraser, Lyn M. And Allen Ormiston. 2004. Memahami Laporan Keuangan. Jakarta: PT Indeks 
Indriawati, Welly Florentia. (2017). Pengaruh Dewan Komisaris Independen, Komite Audit, Kepemilikan Institusional Dan Ukuran Perusahaan Terhadap Penghindaran Pajak Dengan Profitabilitas Sebagai Variabel Moderating. Skripsi, 1-81

Kasmir, 2003.Bank dan Lembaga Keuangan Lainnya, PTRaja Grafindo Persada, Jakarta.

Kasmir,2003. Manajemen Perbankan, Jakarta:PT.Raja Grafindo Persada

Munawir, S. 2010. Analisa Laporan Keuangan (Edisi 4). Liberty, Yogyakarta.

Rico Lesmana, 2003, "Pedoman Menilai Kinerja Untuk Perusahaan Tbk, Yayasan, BUMN, BUMD, dan Organisasi Lainnya”, Edisi Pertama, Jakarta: Elex Media Komputindo.

Sunarto, 2006. Pengantar Manajemen Pemasaran, Cetakan 1. Yogyakarta : Ust. Press.

Santoso, T. B., \& Muid, D. (2014). Pengaruh Corporate Governance Terhadap Penghindaran Pajak Perusahaan. Diponegoro Journal of Accounting, 3 (4) : 1-12

Taswan. 2010. Manajemen Perbankan: Konsep, Teknik, dan Aplikasi. Yogyakarta: UPP STIM YKPN.

www.idx.co.id.html. diakses pada tanggal 14 Desember 2018. 